\title{
WSPÓLNA POLITYKA ROLNA I JEJ KAPITAŁ INSTYTUCJONALNY W OCENIE UŻYTKOWNIKÓW TOWAROWYCH GOSPODARSTW ROLNYCH REGIONU OPOLSKIEGO
}

\section{CAP AND ITS INSTITUTIONAL CAPITAL AS ESTIMATED BY THE USERS OF THE MERCHANDISE AGRICULTURAL HOUSEHOLDS IN OPOLE REGION}

\author{
Stanisława SOKOŁOWSKA • Anna BISAGA \\ Uniwersytet Opolski \\ Wydział Ekonomiczny \\ PI. Kopernika 11a, 45-040 Opole \\ stanislawa.sokolowska@uni.opole.pl• abisaga@uni.opole.pl
}

Zarys treści: Po 10 latach obecności Polski w UE instrumenty Wspólnej Polityki Rolnej wzmocniły rozwój towarowych gospodarstw rolnych, przystosowały je do zarządzania funkcją środowiskową i zapoczątkowały adaptację do gospodarki opartej na wiedzy. Praca jest próbą odpowiedzi na pytanie o znaczenie WPR oraz jej otoczenia instytucjonalnego dla rozwoju towarowych gospodarstw rolnych i obszarów wiejskich regionu opolskiego. Analizowane są opinie i oceny kierowników tego typu gospodarstw zbierane metodą wywiadu kwestionariuszowego w gospodarstwach zlokalizowanych w gminach reprezentatywnych dla rolnictwa Opolszczyzny. Na podstawie badań z 2008 i 2014 r. stwierdzono, że dalsze procesy transformacyjne w rolnictwie i na obszarach wiejskich będą zależeć od „zakorzenienia” w sieciach społecznych rolników dotychczas implementowanego otoczenia instytucjonalnego i oceny jego wpływu na zmiany w gospodarstwach rolnych w różnych płaszczyznach ich funkcjonowania.

Słowa kluczowe: zrównoważony rozwój, terytorium, środowisko instytucjonalne WPR, modernizacja gospodarstw rolnych.

\section{Wstęp}

W literaturze nadal za oczywisty uznaje się pogląd o malejącej roli rolnictwa w gospodarce. Dowodzić tego mają wskaźniki makroekonomiczne, takie jak: udział rolnictwa w tworzeniu PKB, liczba zatrudnionych, liczba gospodarstw domowych użytkujących ziemię jako główne źródło utrzymania, zmniejszająca się powierzchnia użytków rolnych itp. Na podstawie wartości tych samych wskaźników uzyskanych na poziomie mezo-, uzasadniana jest także teza, że silne ekonomicznie rolnictwo nie ma wpływu na rozwój regionalny (Czudec i Kata 2013, s. 58). Takie myślenie wywiera wpływ na dyskusję o Wspólnej Polityce 
Rolnej (WPR): postuluje się jej likwidację albo istotne okrojenie poprzez włączenie Europejskiego Funduszu Rolnego Rozwoju Obszarów Wiejskich do Funduszu Spójności (Hardt 2008 s. 59-63). Wypada zauważyć, że przywołane poglądy dają się utrzymać jedynie przy sektorowym podejściu do gospodarki i w ramach neoklasycznej koncepcji wzrostu gospodarczego, w której kapitał naturalny, ludzki i instytucjonalny są egzogeniczne wobec funkcji produkcji, stanowią bowiem źródło rent ekonomicznych, które zanikają w dłuższej perspektywie czasowej.

Przeciwieństwem podejścia sektorowego jest podejście terytorialne, które jest „zakorzeniane" w WPR od ostatniej dekady XX w. Ten kierunek zmian w WPR został początkowo wywołany różnymi negatywnymi efektami zewnętrznymi rolnictwa industrialnego, głównie środowiskowymi, ale także marnotrawstwem innych zasobów, takich jak: różnorodne tradycje kulturowe, lokalne specjalizacje, nawyki kulinarne, zaufanie towarzyszące sprzedaży bezpośredniej (Bruska 2014, s. 27-29). W rezultacie WPR została podzielona na dwa filary: sektorowy i terytorialny. Drugi z nich miał wspierać utrzymanie albo rewitalizację takich funkcji gospodarstw rolnych, które służą rozwojowi lokalnemu i regionalnemu.

Zmiana ta dokonywała się w warunkach restrukturyzacji kapitalizmu, cechującej się większą elastycznością zarządzania, decentralizacją i usieciowieniem firm, znaczącym wzrostem kapitału w zestawieniu z siłą roboczą, indywidualizacją i dywersyfikacją stosunków pracy, wzmagającą się globalną konkurencją, itp. (Castells 2011, s. 43). Niezwykle ważne dla zapewnienia szybkości i sprawności tych procesów były innowacje techniczne budujące technologiczny paradygmat informacjonizmu. Zapewnił on dynamiczny rozwój gospodarki sieciowej i stworzył nowe struktury kierowania. Integracja pionowa, właściwa dla sektorowej organizacji gospodarki, jest zastępowana przez organizację sieciową oraz ekosystemy biznesu, które tworzą: klienci, rynki, produkty, procesy, organizacje, interesariusze, społeczności oraz działania organizacji rządowych (Adner 2012, s. 306). Ekosystemy biznesu wykorzystują nie tylko wiedzę i innowacje, ale również kapitał naturalny, społeczny oraz instytucjonalny dla kreowania nowych łańcuchów wartości i są zorientowane na renty nowego typu, głównie przedsiębiorczą, innowacyjną i sieciową (Niemczyk 2013, s. 25-38). Mogą one stanowić też źródło wartości dodanej w rolnictwie, o ile istniejące skupienia produkcyjne zostaną poddane dalszym procesom modernizacyjnym ukierunkowanym na przekształcanie lokalnych systemów produkcji w inteligentne specjalizacje. Takie endogeniczne zmiany technologiczne mogą skutkować powstawaniem nowych „centrów wzrostu”, a dzięki mechanizmom społeczeństwa informacyjnego ulegać dyfuzji na inne obszary wiejskie i budować nowe powiązania w ramach partnerstwa miejsko-wiejskiego (Bisaga 2013, s. 227-230).

Wspomniane wcześniej poszukiwanie rent nowego typu jest przesłanką myślenia strategicznego, które cechuje nie tylko ekosystemy biznesu, ale również działania przedsiębiorczych samorządów lokalnych i regionalnych (Barczyk 2010, s. 171-180). Planowanie na poziomie całej Unii Europejskiej ma natomiast przyspieszyć indukowanie takich strategii, także przez upowszechnianie i właściwe zdefiniowanie konceptualnych uwarunkowań rozwoju. Zrównoważony rozwój akcentowany w tych planach ma zgodnie z założeniami strategii „Europa 2020” dodatkowo wywołać „zielony wzrost” i sprzyjać większemu włączeniu społecznemu. Dla przyszłego rozwoju obszarów wiejskich istotne znaczenie posiada natomiast:

- tworzenie warunków do „układania się” rolnictwa w gospodarce opartej na wiedzy i przeznaczenia w programie „Horyzont 2020” rekordowej kwoty 2,4 bln euro 
na badania naukowe w rolnictwie, innowacje procesowe i produktowe oraz ich promocję (biogospodarka),

- budowanie infrastruktury informacyjnej służącej zarówno dyfuzji wiedzy, informacji i dobrych praktyk, jak też sieciowej transformacji gospodarki żywnościowej,

- wdrażanie instytucjonalnych rozwiązań pozwalających na integrację instrumentów różnych funduszy europejskich na poziomie regionalnym i lokalnym, w tym także na obszarach wyodrębnionych gospodarczo z różnych jednostek administracyjnych.

W krajowych dokumentach strategicznych nowy model rozwoju najpełniej przedstawiony został w Krajowej Strategii Rozwoju Regionalnego 2010-2020 i Koncepcji Przestrzennego Zagospodarowania Kraju 2030. Uwzględniając logikę tych dokumentów i na podstawie zarysowanych ram teoretycznych w opracowaniu przyjęto założenie, że sektorowe instrumenty WPR należy postrzegać również w świetle ich funkcji terytorialnych. Zgodnie z tym założeniem pomijanie znaczenia rolnictwa towarowego w rozwoju obszarów wiejskich jest zabiegiem czysto konceptualnym, który ma negatywne skutki w praktyce zarządzania, szczególnie na poziomie lokalnym. Dodatkowo nie będzie ono ułatwiać wykorzystania instrumentów rozwojowych obszarów wiejskich nie tyle o charakterze krajowym, co tworzonych przez Komisję Europejską dla całej przestrzeni europejskiej np. związanych z Europejskim Partnerstwem Innowacyjnym na rzecz Wydajnego i Zrównoważonego Rolnictwa, Zintegrowanymi Inwestycjami Terytorialnymi, ale głównie z instrumentem: rozwój lokalny kierowany przez społeczność.

Można przyjąć, że dalsze procesy transformacyjne w rolnictwie i na obszarach wiejskich będą zależeć od „zakorzenienia” w sieciach społecznych rolników dotychczas implementowanego otoczenia instytucjonalnego i oceny jego wpływu na zmiany w gospodarstwach rolnych z uwzględnieniem różnych płaszczyzn ich funkcjonowania. W literaturze dominuje ocena wpływu WPR na rozwój rolnictwa w polskich regionach oparta na analizie wykorzystania wsparcia, które ta polityka gwarantuje rolnikom; ewentualnie na ocenie alokacji tego wsparcia pomiędzy różne instrumenty. Coraz częściej podejmowany jest też problem zmiany instytucjonalnej związanej z wdrażaniem europejskiego modelu rolnictwa. Paradoksalnie dla rolników z województwa opolskiego powstanie i ciągła modyfikacja środowiska instytucjonalnego określającego „reguły gry” w rolnictwie ma większe znaczenie niż wielkość wsparcia uzyskiwanego bezpośrednio. Na taki ogólny wniosek składają się analizy wyników badań przeprowadzonych metodą wywiadu kwestionariuszowego w celowo dobranych gospodarstwach rolnych zlokalizowanych w gminach reprezentatywnych dla rolnictwa Opolszczyzny: Głogówek, Kietrz, Lubrza, Biała, Skarbimierz i Olszanka. W 2008 r. próba badawcza składała się ze 150 gospodarstw, a w 2014 r. liczyła 100 gospodarstw proporcjonalnie dobranych z poprzedniej próby (Bisaga i in. 2010). Jeżeli nawet rolnictwo Opolszczyzny nie jest reprezentatywne w skali kraju, to występujące w nim silniejsze procesy rozwojowe potwierdzają rolę równowagi instytucjonalnej w dynamizowaniu procesów modernizacyjnych. Niepewność związana z otoczeniem instytucjonalnym skłania do zachowań rutynowych. Zaufanie w relacjach z instytucjami zachęca do podejmowania ryzyka związanego z nowymi funkcjami gospodarstw rolnych. Z tego względu towarowe rolnictwo Opolszczyzny może być traktowane jako ciekawy przypadek do badań nad rolą instytucji w wyznaczaniu ścieżek modernizacyjnych gospodarstw rolnych. 


\section{Gospodarstwo rolne jako instytucja}

Powszechne w opinii publicznej, ale obecne też w literaturze, traktowanie rolników jako jedynie beneficjentów WPR zostanie w opracowaniu zastąpione ujęciem ich jako decydentów dążących do takiego zespolenia zasobów i umiejętności, które pozwala na optymalną realizację transakcji rynkowych i instytucjonalnych. Ponadto nacisk zostanie położony na „zakorzenienie” rolnika w zewnętrznych strukturach, które w istotny sposób wpływają na instytucjonalne wyodrębnienie gospodarstw rolnych i tematyzują obszary skutecznych decyzji.

Nie tylko gospodarka podlega zmianom, zmienia się także realizowana polityka gospodarcza. Pomiędzy tymi procesami powstają „ścieżki zależności” (North 1997, s. 13-18), prowadzące do różnorodnych dróg rozwoju, na które ponadto mają wpływ: dziedzictwo kulturowe i specyficzne historyczne doświadczenie ekonomiczne. Przy takim rozumieniu zmiany, gotowość do jej wprowadzenia oraz jej ukierunkowanie są związane z siłą istniejących instytucji oraz możliwością uzyskania wsparcia ze strony respektowanego $\mathrm{w}$ danej społeczności systemu wartości. Stopień równowagi instytucjonalnej rozumiany jako swoista wiązka sprzężeń zwrotnych pomiędzy normami formalnymi (prawo, standardy, procedury, dobre praktyki) i nieformalnymi (obyczaje, tradycje, głęboko „zakorzenione” rutyny) wydaje się być głównym czynnikiem różnicującym procesy modernizacyjne w rolnictwie polskich regionów i prowadzi do wzrostu dywergencji rolnictwa w Polsce. Innym obszarem, w którym taki rodzaj sprzężeń odgrywa istotną rolę jest instytucjonalne wyodrębnienie jednostki produkcyjnej. Wynikająca z "reguł gry” samoocena rolnika ma zasadniczy wpływ na definiowanie kryteriów sukcesu oraz sposoby podejmowania decyzji prowadzących do ich realizacji.

Zgodna z doświadczeniem pierwszej modernizacji (prostego uprzemysłowienia) instytucjonalna transformacja gospodarstw rolnych miała przebiegać od chłopa przez rolnika do farmera. Polska jednak wstąpiła do UE w takim momencie jej dziejów, kiedy do WPR wdrażano nowe zasady w istotny sposób ograniczające dalszą industrializację rolnictwa. Decyzje produkcyjne stawały się niezależne od wsparcia finansowego (decupling) i były obarczone różnymi wymaganiami środowiskowymi, które są sukcesywnie nawarstwiane zgodnie z logiką drabiny zrównoważonego rozwoju środowiskowego. Tak zmodyfikowana matryca instytucjonalna WPR tworzyła pole wyborów dla użytkowników gospodarstw rolnych w Polsce, uruchamiając procesy adaptacyjne.

Powstający model rolnictwa jest identyfikowany jako ponowoczesny (Zegar 2012, s. 21-22), jednak uwzględniając wszystkie aspekty dokonującej się restrukturyzacji kapitalizmu można postawić tezę, że stanowi on początek nowego etapu modernizacji. Adaptacja gospodarstw rolnych do nowego modelu rolnictwa europejskiego (rolnictwa wielofunkcyjnego) kierowana „regułami gry” zmodyfikowanej matrycy instytucjonalnej WPR zmienia postrzeganie gospodarstw w oczach ich użytkowników - dokonują oni również przewartościowania swojej roli społeczno-gospodarczej. W tabeli 1 przestawiono opinie respondentów dotyczące identyfikacji instytucjonalnej użytkowanej jednostki produkcyjnej. 
Tabela 1. Instytucjonalne wyodrębnienie użytkowanej jednostki produkcyjnej w opinii badanych rolników

\begin{tabular}{|l|c|c|}
\hline \multirow{2}{*}{ Rodzaj instytucji } & $\mathbf{2}$ Wskazania w\% \\
\cline { 2 - 3 } & $\mathbf{2 0 0 8}$ & $\mathbf{2 0 1 4}$ \\
\hline Gospodarstwo chłopskie & 59 & 33 \\
Małe, średnie przedsiębiorstwo & 16 & 37 \\
Farma & 5 & 20 \\
Trudno powiedzieć & 20 & 10 \\
\hline
\end{tabular}

Źródło: opracowanie własne na podstawie badań przeprowadzonych w woj. opolskim w 2008 i 2014 r.

Teza, że gospodarstwo rolne to też przedsiębiorstwo jest obecna w pracach ekonomistów rolnych, którzy do zasobów gospodarstw włączają zarządzanie (Kulawik 2008, s. 33-34; Tomczak 2009 i in.), a jednocześnie podejmują problem umiejscowienia polskiego rolnictwa w hierarchii rozwoju gospodarczego „i sformułowania na tej zasadzie strategii dotyczącej wizji rolnictwa w świetle analizy doświadczeń i uwarunkowań krajowych, europejskich i światowych" (Tomczak 2009, s. 176).

$\mathrm{Na}$ obszarach wiejskich rośnie presja na zwiększanie świadczeń gospodarstw produkcyjnych na rzecz gospodarstw domowych i ekonomii rodziny. Z badań przeprowadzonych w 2014 r. wynika, że rolnikom z województwa opolskiego uzyskiwane dochody pozwalają na:

- utrzymanie rodziny - 75\% wskazań,

- zapewnienie wykształcenia dzieciom i stabilizacji materialnej-45\%,

- inwestycje w gospodarstwie - 37\%,

- inwestycje w budynki mieszkalne - $17 \%$.

Rosnąca presja dochodowa wpływa na identyfikację kryteriów sukcesu w działalności gospodarczej (zob. tabela 2).

Tabela 2. Kryteria sukcesu w działalności gospodarczej

\begin{tabular}{|l|c|c|}
\hline \multirow{2}{*}{\multicolumn{1}{|c|}{ Kryterium }} & $\mathbf{2}$ Wskazania w\% \\
\cline { 2 - 3 } & $\mathbf{2 0 0 8}$ & $\mathbf{2 0 1 4}$ \\
\hline Zysk & 89 & 90 \\
Udział w rynku & 49 & 36 \\
Zadowolenie odbiorców & 27 & 22 \\
Zapewnienie sukcesji w gospodarstwie & 21 & 8 \\
Prestiż agrobiznesmena & 5 & 11 \\
\hline
\end{tabular}

Źródło: jak pod tabelą 1.

Świadomość prowadzenia gospodarstwa rolnego jako biznesu jest niezbędna, aby gospodarstwo nie tylko trwało, ale rozwijało się wewnętrznie i mogło wykazywać zewnętrzną ekspansję, która cechuje towarowe gospodarstwa rolne z województwa opolskiego.

Zjawisko powiększania obszaru gospodarstw rolnych w regionie opolskim jest widoczne od początku transformacji systemowej, jednak proces ten nasilił się po akcesji Polski do UE. Ziemia będąca własnością użytkowników towarowych gospodarstw rolnych z województwa opolskiego pochodzi głównie z sukcesji w ramach rodziny (89\% wskazań w 2014 r.), została zakupiona od innych rolników indywidualnych (66\%) bądź nabyta od Skarbu Państwa (21\%). Powiększanie areału użytkowanej ziemi stanowi nadal 
jeden z głównych celów strategicznych kierowników gospodarstw. W badaniach z 2014 r. 73\% respondentów planuje dokupienie ziemi, a 46\% powiększenie użytkowanego areału poprzez dzierżawę, głównie sąsiedzką. Po akcesji Polski do UE instytucja ta uległa znacznemu wzmocnieniu, również ze względu na procesy depopulacji wsi opolskiej połączone z przekonaniem o konieczności utrzymania użytków rolnych w dobrej kulturze. Bardzo często tak dzierżawione grunty są wykupywane od przebywającego za granicą ich właściciela. Dzięki dzierżawie sąsiedzkiej możliwe było także bardzo sprawne wdrażanie instrumentu rent strukturalnych.

Określając korzyści, jakich oczekują od integracji Polski z UE, rolnicy wskazywali głównie na poprawę opłacalności produkcji (Sokołowska i in. 2006, s. 98). Po dziesięciu latach obecności Polski w UE większość badanych potwierdza, że ich dochody poprawiły się bądź znacząco (20\% wskazań), bądź nieznacznie (50\%), co w istotny sposób ograniczyło niepewność w zarządzaniu rolniczym warsztatem produkcyjnym i sprzyjało decyzjom przyspieszającym specjalizację produkcji.

\section{Instytucjonalne uwarunkowania zarządzania funkcją środowiskową gospodarstw rolnych}

Podstawowy obszar modyfikacji matrycy instytucjonalnej WPR dotyczy jej ekologizacji. Należy jednak podkreślić, że wspomniane we wstępie rozwiązania normatywne nie miały służyć jedynie włączeniu gospodarstw do zarządzania środowiskowego - ekologizacja produkcji rolnej otwierała etap refleksyjnej (tzn. opartej na wiedzy) modernizacji gospodarstw. Wdrażane od 2003 r. wymagania SMR (Statutory Management Requirements) i GAEC (Good Agricultural and Environmental Conditions) należy traktować jako pierwszy szczebel drabiny zrównoważonego rozwoju w rolnictwie, zaś dyfuzja wiedzy dotycząca nowych zasad gospodarowania była jedynie pierwszym zadaniem zreformowanego systemu doradztwa rolniczego (SDR).

Drabina zrównoważonego rozwoju opiera się na zasadach trwałości kapitału naturalnego zgodnie ze słabą, wrażliwą, silną lub restrykcyjną zasadą trwałości. Według S. Czai (2013, s. 277) „Pierwsze oznacza zachowanie wielkości całkowitego kapitału (naturalnego, antropogenicznego i społecznego) bez uwzględniania jego struktury. Wrażliwa zasada każe zachować całość kapitału i odpowiednią jego strukturę. Silna zasada zwraca uwagę na konieczność zachowania każdego kapitału z osobna, natomiast zasada restrykcyjna zakazuje uszczuplenia któregokolwiek z zasobów". Jej wdrażanie, o ile ma być skuteczne i społecznie odpowiedzialne, musi uwzględniać ekologiczną delimitację przestrzeni europejskiej, krajowej, regionalnej i lokalnej. W Polsce istotna propozycja takiej delimitacji została przedstawiono w Koncepcji Przestrzennego Zagospodarowania Kraju 2030, chociaż zawarte w tym dokumencie mapowanie różnych kategorii obszarów chronionych musi być nie tylko uszczegółowione, ale przede wszystkim wymaga konkretnych rozwiązań instytucjonalnych. Zakładając, że we wdrażaniu drabiny zrównoważonego rozwoju będzie dominować podejście terytorialne, należy przypuszczać, że również instrumenty WPR w tym zakresie będą ulegać coraz większej regionalizacji, żeby ostatecznie zostać przypisane do określonego miejsca. Jest to, jak można sądzić, długi proces ewolucyjny, ale ryzyka klimatyczne oraz utrata bioróżnorodności postępująca w tempie geometrycznym mogą ten proces mocna zdynamizować. 
Od momentu akcesji Polski do UE instrumenty zarządzania środowiskowego w rolnictwie są wdrażane ewolucyjnie. Na podstawie badań z 2008 r. stopień poinformowania użytkowników towarowych gospodarstw rolnych w regionie o wymaganiach zasady współzależności był wysoki - 63\% badanych potwierdziło ich znajomość, 33\% zaprzeczyło, a $4 \%$ respondentów miało trudności z oceną swojej wiedzy w tym zakresie. Jednak dopiero od 2013 r. gospodarstwa rolne w Polsce obowiązują te same co pozostałych rolników w UE uregulowania instytucjonalne w dziedzinie ochrony przyrody. Nic dziwnego, że w edycji badań z 2014 r. rolnicy potwierdzają posiadanie wiedzy nt. dobrej kultury rolnej i SMR w stopniu niezbędnym do prowadzenia swojej działalności (68\% wskazań). Wśród pozostałych respondentów 21\% deklarowało pełną wiedzę w tym zakresie, 10\% miało dopiero zamiar zapoznać się z nowymi wymaganiami, a 1\% nie było zainteresowanych taką wiedzą.

W perspektywie średniookresowej 2014-2020 obowiązywać będą wymogi „zazielenienia", których spełnienie ma skutkować wzrostem dopłat bezpośrednich o 30\%, tj. około 74 euro/ha. Instrument ten zakłada dywersyfikację upraw (również przez udział w programach rolnośrodowiskowych), utrzymanie trwałych użytków zielonych oraz utrzymanie obszarów proekologicznych. Dzięki zazielenieniu również Europejski Fundusz Rolny Gwarancji będzie uczestniczyć w zarządzaniu przestrzenią obszarów wiejskich Europy. Rolnicy z opolskiego powstrzymują się na razie od oceny tego instrumentu (52\% wskazań). Jedynie $23 \%$ respondentów ocenia je jako bardzo korzystne lub korzystne. Niestety aż 25\% badanych uznaje tę zmianę za niekorzystną.

Procedury „zazielenienia” wzmacniają natomiast zainteresowanie programami rolnośrodowiskowymi (zob. tab. 3).

Tabela 3. Zakres uczestnictwa rolników w pakietach programów rolnośrodowiskowych

\begin{tabular}{|c|c|c|c|c|}
\hline \multirow[b]{2}{*}{ Pakiet programu } & \multicolumn{2}{|c|}{2008} & \multicolumn{2}{|c|}{2014} \\
\hline & uczestniczę & $\begin{array}{l}\text { zamierzam } \\
\text { uczestniczyć }\end{array}$ & uczestniczę & $\begin{array}{l}\text { zamierzam } \\
\text { uczestniczyć }\end{array}$ \\
\hline Rolnictwo zrównoważone & 9 & 33 & 44 & 29 \\
\hline Rolnictwo ekologiczne & 5 & 9 & 1 & 5 \\
\hline Ekstensywne trwałe użytki zielone & 1 & 3 & 1 & 6 \\
\hline $\begin{array}{l}\text { Ochrona zagrożonych gatunków } \\
\text { ptaków i siedlisk przyrodniczych poza } \\
\text { obszarem Natura } 2000\end{array}$ & 0 & 2 & 0 & 2 \\
\hline $\begin{array}{l}\text { Ochrona zagrożonych gatunków } \\
\text { ptaków i siedlisk przyrodniczych } \\
\text { na obszarach Natura } 2000\end{array}$ & 1 & 1 & 0 & 2 \\
\hline $\begin{array}{l}\text { Zachowanie zagrożonych zasobów } \\
\text { genetycznych roślin w rolnictwie }\end{array}$ & 1 & 2 & 1 & 1 \\
\hline $\begin{array}{l}\text { Zachowanie zagrożonych zasobów } \\
\text { genetycznych zwierząt w rolnictwie }\end{array}$ & 2 & 3 & 1 & 1 \\
\hline Ochrona gleb i wód & 15 & 27 & 24 & 21 \\
\hline Strefy buforowe & 0 & 7 & 0 & 9 \\
\hline
\end{tabular}

Źródło: jak pod tabelą 1. 
W regionie opolskim dominuje rolnictwo intensywne środowiskowo (Czyżewski i Smędzik-Ambroży 2013, s. 88-98). Prezentowane badania własne potwierdzają, że po wstąpieniu Polski do UE nasiliły się procesy upraszczania produkcji w gospodarstwach roślinnych, przy jednoczesnym wzroście areału użytkowanej ziemi (przede wszystkim dzięki dzierżawie sąsiedzkiej). Proces ten wymaga ochrony świadczeń ekosystemów, głównie gleby. Zainteresowanie programami rolnośrodowiskowymi wynika ze stosunku rolników do utrzymania trwałości jakości ekosystemów: 73\% respondentów potwierdza, że gospodarstwa rolne powinny być premiowane za utrzymanie jakości ekosystemów, 14\% nie widzi takiej potrzeby, ponieważ ich zdaniem działania takie są wpisane w zawód rolnika, natomiast 12\% twierdzi, że premiowane powinny być jedynie działania ponadnormatywne. W tych warunkach należy rozważyć metody regionalnego różnicowania i stosowania indywidualnej kalkulacji programów rolnośrodowiskowych. Wydaje się, że bez wdrożenia takich instrumentów cele Koncepcji Przestrzennego Zagospodarowania Kraju 2030 dotyczące obszarów wiejskich i korytarzy ekologicznych będą trudne do osiągnięcia, ponieważ dla utrzymaniu świadczeń ekosystemów, oprócz indywidualnych zobowiązań rolników, potrzebne są działania zbiorowe. W regionie opolskim tylko 51\% badanych widzi potrzebę współpracy rolników w realizacji programów rolnośrodowiskowych. Interesująca jest też ich opinia w kwestii, kto powinien inicjować taką współpracę (zob. tab. 4).

Tabela 4. Instytucje uprawnione do inicjowania współpracy

\begin{tabular}{|l|c|}
\hline \multicolumn{1}{|c|}{$\quad$ Inicjatorzy współpracy } & Wskazania w\% \\
\hline Gmina w oparciu o lokalne plany ochrony środowiska & 29 \\
Zainteresowani rolnicy & 31 \\
Oddziały terenowe ARiMR & 41 \\
Urząd marszałkowski w oparciu o regionalne strategie ochrony środowiska & 9 \\
Grupy „Odnowy Wsi” & 7 \\
Lokalne Grupy Działania & 11 \\
\hline
\end{tabular}

Źródło: opracowanie własne na podstawie badań przeprowadzonych w woj. opolskim w 2014 r.

Na podstawie przedstawionych danych widać rolę różnych instytucji w zarządzaniu modernizacją ekologiczną gospodarstw. Badani podkreślają rolę organizacji lokalnych, takich jak LGD oraz samorządów, które na Opolszczyźnie w większości nie uwzględniały rolnictwa w swoich planach rozwoju.

\section{Matryca instytucjonalna WPR a zasoby relacyjne gospodarstw rolnych}

Endogenizacja rozwoju gospodarstw rolnych, jako kolejny etap ich modernizacji, wymaga oddzielenia celów powszechnych gospodarowania od celów autonomicznych. Takie cele powszechne jak: zysk, efekty skali, udział w rynku zostały „zakorzenione” w rolnictwie dzięki pierwszej modernizacji. Nowy jej etap nie zaprzecza tym celom, każe odnosić się do nich w sposób refleksyjny (uwzględniający wiedzę o ich skutkach). Cele autonomiczne można zdefiniować jako to, co gospodarstwo potrafi robić najlepiej, uwzględniając warunki środowiskowo-klimatyczne, instytucjonalne reguły gry, możliwości współpracy, posia- 
dane umiejętności. Realizacja tych celów decyduje o indywidualnym, niepowtarzalnym kształcie wielofunkcyjności każdego modernizującego się gospodarstwa rolnego.

W coraz większym stopniu od właściwego zdefiniowania celów autonomicznych będzie zależeć realizacja celów powszechnych i możliwość kreowania wartości dodanej. Ranking kategorii celów autonomicznych, których realizacja ma zapewnić rolnikom z opolskiego wyższe dochody przedstawiał się w 2014 r. następująco:

1) optymalizacja technologicznych możliwości specjalizacji,

2) zdobywanie wiedzy i ustawiczne kształcenie,

3) maksymalizacja korzyści z wprowadzanych innowacji,

4) minimalizacja kosztów inwestycji,

5) dostęp do „lepszych” źródeł informacji,

6) minimalizacja kosztów transakcyjnych.

W świetle przedstawionego rankingu zrozumiała wydaje się chęć dużej grupy użytkowników towarowych gospodarstw rolnych uczestniczenia w platformach współpracy skupiających także ośrodki wdrożeniowe i ośrodki akademickie (zob. tab. 5).

Tabela 5. Zainteresowanie platformami współpracy w regionie opolskim

\begin{tabular}{|l|c|}
\hline \multicolumn{1}{|c|}{ Obszar współpracy } & Wskazania w\% \\
\hline Nowe technologie produkcji & 67 \\
Specjalizacja gospodarstw zgodna z uwarunkowaniami środowiskowymi & 60 \\
Instrumenty marketingowe & 56 \\
Certyfikowane systemy zarządzania jakością & 51 \\
\hline
\end{tabular}

Źródło: jak pod tabelą 4.

Adaptacja rolnictwa do gospodarki opartej na wiedzy wymagać będzie także innych innowacji instytucjonalnych. Główny problem polega na tym, że w obecnej perspektywie średniookresowej instytucje te powinny być kreowane oddolnie. Otwarta pozostaje kwestia inicjatorów, którzy podejmą się wysiłku konstruowania nowych instytucji. W ostatniej edycji prezentowanych badań respondentów zapytano o główne bariery współpracy rolników (zob. tab. 6).

Tabela 6. Bariery ograniczające uczestnictwo rolników w sieciach komunikacji i współpracy

\begin{tabular}{|l|c|}
\hline \multicolumn{1}{|c|}{ Bariery współpracy } & Wskazania w\% \\
\hline Niechęć do wspólnego działania & 30 \\
Brak zaufania i obawa przed niedotrzymaniem zobowiązań & 55 \\
Brak platform współpracy & 18 \\
Nieprzychylny stosunek społeczności lokalnych do działań grupowych rolników & 12 \\
Dystans rolników do inicjatorów działań zespołowych & 24 \\
\hline
\end{tabular}

Źródło: jak pod tabelą 1.

Współpraca rodzi efekty zewnętrzne stanowiące rodzaj korzyści zewnętrznych. Ich wykorzystanie w procesie podejmowania decyzji wymaga nowych umiejętności zarządczych. Jak widać umiejętności te nie powstają w sieciach współpracy. Obecnie budowane są one dzięki relacjom z instytucjami - organizacjami otoczenia rolnictwa, ale również przedsta- 
wicielami handlowymi, bankami, agentami ubezpieczeniowymi lub grupami LGD. Badani rolnicy identyfikują te relacje jako czynniki wpływające na rozwój ich gospodarstw (zob. tab. 7).

Tabela 7. Wpływ instytucji na rozwój gospodarstw rolnych w opinii respondentów

\begin{tabular}{|l|c|}
\hline \multicolumn{1}{|c|}{ Nazwa instytucji } & Wskazania w\% \\
\hline Agencja Rynku Rolnego & 38 \\
Agencja Restrukturyzacji i Modernizacji Rolnictwa & 75 \\
ODR & 57 \\
Agencja Nieruchomości Rolnych & 23 \\
Izba Rolnicza & 10 \\
Samorząd terytorialny & 16 \\
Związki branżowe & 14 \\
Grupy producenckie & 32 \\
Organizacje Mniejszości Niemieckiej & 3 \\
Lokalne Grupy Działania & 7 \\
Lokalne sieci dobrej żywności & 2 \\
\hline
\end{tabular}

źródło: jak pod tabelą 4.

Wieś opolska ma coraz bardziej posttradycyjny charakter. Pozycje społeczne, więzi, umiejętności nie są dziedziczone jedynie w rodzinie i wspólnocie, lecz są konstruowane, czemu sprzyja zmodyfikowana matryca instytucjonalna WPR. Nie oznacza to wcale, że opolska wieś jest odmiejscowiona, pozbawiona tradycji. Oznacza to tylko tyle, że jej mieszkańcy muszą podejmować permanentny wysiłek odtwarzania tradycji w celu zachowania tożsamości regionalnej. Wysoka pozycja instytucji stanowionych w relacjach rolników z otoczeniem wynika z możliwości uzyskania rent instytucjonalnych wspierających ich wysiłki modernizacyjne. Rosnące znaczenie instytucji powstających oddolnie (spontanicznie) pokazuje jednak na terytorialne zakorzenienie gospodarstw rolnych. W chwili obecnej jedynie 29\% respondentów jest zainteresowanych współpracą z lokalnymi sieciami dobrej żywności, jednak w opinii rolników może ono wzrastać w zależności od aktywności lokalnych grup działania.

Utrwalanie się relacji z otoczeniem instytucjonalnym w istotny sposób wpływa na proces podejmowania decyzji. Już w 2008 r. zauważono istotną zmianę w modelu podejmowania decyzji. Są one głównie konsultowane z członkami rodziny i przyjaciółmi. Na trzecim miejscu rolnicy wskazują doradców rolnych i dopiero na czwartym innych rolników, którzy osiągają sukcesy. Zmianę tę potwierdzają wyniki badań z 2014 r.

W badaniach zidentyfikowano także lukę instytucjonalną, która stanowi barierę rozwoju przedsiębiorczych gospodarstw rolnych. Jest ona związana z instytucjami regulującymi rynek rolny. Według D. C. Northa (1997, s. 13-18) istnienie rynku bez instytucji jest niemożliwe, ponieważ utrudnia budowanie powiązań międzyorganizacyjnych, a proces transakcyjny związany jest z dużym ryzykiem. W tabeli 8 przedstawiono opinie rolników na temat powiązań organizacyjnych istotnych dla rozwoju ich jednostek produkcyjnych. 
Tabela 8. Powiązania międzyorganizacyjne istotne dla rozwoju gospodarstw rolnych

\begin{tabular}{|l|c|}
\hline \multicolumn{1}{|c|}{ Powiązania z: } & Wskazania w\% \\
\hline innymi rolnikami & 36 \\
zakładami przetwórstwa rolno-spożywczego & 47 \\
sieciami handlowymi & 20 \\
konsumentami & 15 \\
\hline
\end{tabular}

Źródło: jak pod tabelą 4.

Jak wynika z danych zawartych w tabeli 8, najistotniejsze znaczenie dla rozwoju gospodarstw mają powiązania międzyorganizacyjne z zakładami przetwórstwa rolno-spożywczego. Respondenci postulują nawet, aby współpraca w ramach łańcuchów dostaw była wspierana instrumentami PROW 2014-2020 (48\% wskazań). Jest to także, poza zachowaniem ziemi dla krajowych producentów, istotny argument, który w przekonaniu badanych rolników ma przemawiać za potrzebą krajowej polityki rolnej. Problem polega jednak na tym, że zgodnie z nową dyrektywą dotyczącą regulacji rynków rolnych w UE (Rozporzq̨dzenie...2013) to organizacje rolnicze i ich zrzeszenia powinny występować jako instytucje kształtujące powiązania międzyorganizacyjne gospodarstw z innymi węzłami sieci łańcucha żywnościowego. Kreowanie takich sieci powiązań jest też wyzwaniem dla instytucji lokalnych i regionalnych.

Realizowane przez gospodarstwa rolne cele autonomiczne, decydujące o stopniu i charakterze ich wielofunkcyjności, powinny też sprzyjać ich zakorzenieniu terytorialnemu. Interesujące są opinie badanych rolników na temat różnych funkcji gospodarstw, pozytywnie postrzeganych przez otoczenie (zob. tab. 9).

Tabela 9. Terytorialne funkcje gospodarstw rolnych w ocenie społeczności lokalnych

\begin{tabular}{|l|c|}
\hline \multicolumn{1}{|c|}{ Funkcje gospodarstw rolnych } & Wskazania w\% \\
\hline Utrzymanie gleb w dobrej kulturze rolnej & 61 \\
Pielęgnacja krajobrazu & 57 \\
Utrzymanie bioróżnorodności & 48 \\
Zachowanie tradycji kulturowych i tożsamości lokalnej & 63 \\
Zapewnienie wyższej jakości życia na obszarach wiejskich & 65 \\
Kreowanie dochodów społeczności lokalnej & 50 \\
\hline
\end{tabular}

Źródło: jak pod tabelą 4.

Pomimo istotnych funkcji terytorialnych realizowanych przez gospodarstwa rolne, nie zawsze są one doceniane przez mieszkańców wsi, a potrzeby rolników w niewielkim stopniu uwzględniane w planach rozwojowych gminy - tak uważa 45\% respondentów i tylko $4 \%$ jest zdania, że sprawy rolnictwa są preferowane $w$ gminie. 


\section{Zakończenie}

W opracowaniu przyjęto założenie, że sektorowe instrumenty WPR należy postrzegać również w świetle ich funkcji terytorialnych. Kategoria terytorium była dotychczas obecna w naukach ekonomicznych jako ziemia, miejsce lokalizacji. W jej definiowaniu pomijano specyficzność terytorium rozumianą jako specyficzność relacji, jakie w nim zachodzą. W nowym ujęciu terytorium zaczyna być postrzegane jako forma organizacji redukująca niepewność i ryzyko, stanowiąca źródło informacji, kumulowania i transferu wiedzy oraz umiejętności, ale również jako źródło innowacyjności (Pietrzyk 2001, s. 20). Wydaje się, że reformy WPR wdrażane w XXI w. posiłkują się w rozumieniu obszarów wiejskich właśnie taką definicją. Zmodyfikowana matryca instytucjonalna tej polityki wpływa bowiem na większą przedsiębiorczość rolników, powstawanie sieci społecznych na obszarach wiejskich, tworzy warunki do dyfuzji wiedzy i innowacji oraz poziomych powiązań międzyorganizacyjnych. Przy takim rozumieniu terytorium, odmiejscowienie rolnictwa towarowego pozbawia obszary wiejskie istotnego potencjału rozwojowego.

Użytkowników towarowych gospodarstw rolnych z województwa opolskiego cechuje silna tożsamość regionalna. We wszystkich edycjach badań podkreślają, że region opolski posiada własne tradycje społeczno-kulturowe, jest na wyższym poziomie rozwoju społeczno-gospodarczego, a rolnictwo jest jednym z głównych filarów regionalnej gospodarki. Tradycje społeczno-kulturowe i specyficzne historyczne doświadczenia ekonomiczne pozostają w równowadze z nowymi rozwiązaniami instytucjonalnymi WPR. Początkowo kapitał instytucjonalny tej polityki ujawnił swoją siłę w procesie ekologicznej modernizacji gospodarstw, czego skutkiem jest wyższy niż w innych regionach stopień zrównoważenia rolnictwa (Zegar 2014, s. 89). Teraz służy on budowaniu potencjału konkurencji i współpracy na obszarach wiejskich regionu.

Użytkownicy towarowych gospodarstw rolnych doświadczają „wykorzenienia” z przestrzeni wiejskiej, pomimo wielu funkcji gospodarstw, które podnoszą jej jakość. Włączenie instytucji otoczenia rolnictwa, zarówno tych stanowionych, jak też tworzonych przez mieszkańców wsi, do struktur współzarządzania rozwojem regionalnym i lokalnym pozwoli na ponowne „zakorzenienie" towarowych gospodarstw rolnych w konkretnym terytorium i będzie sprzyjać wykorzystaniu tkwiących w nich potencjałów rozwojowych.

Środowisko instytucjonalne WPR doskonali zarządzanie w gospodarstwach rolnych, otwierając nowy etap ich modernizacji związany z budowaniem aktywnego zaufania do wiedzy eksperckiej i posiłkowaniem się w zarządzaniu instrumentami społeczeństwa informacyjnego, czego wyrazem są nowe cele autonomiczne gospodarstw decydujące o ich indywidualnej wielofunkcyjności. Zachodzący proces odróżniania celów autonomicznych gospodarstw rolnych od celów powszechnych gospodarowania stanowi mechanizm endogenizacji rozwoju oraz ponownego „zakorzenienia” gospodarstw w przestrzeni wiejskiej. Jeżeli reformy WPR z początku XXI w. sprzyjały takim rozróżnieniom w doskonaleniu (transformacji) zarządzania gospodarstwami rolnymi, to nowy paradygmat rozwoju regionalnego i orientacja na „zielony wzrost” tworzy instytucje pozwalające na ich ponowne zespolenie, nie tylko dzięki rentom instytucjonalnym, ale głównie pozytywnym sprzężeniom zwrotnym gospodarki sieciowej. 


\section{Literatura}

Adner R., 2012, The Wide Lens: A New Strategy for Innovation, Penguin Books, New York, 306.

Barczyk S., 2010, Przedsiębiorczy samorzqd lokalny i jego instytucje, Wydawnictwo AE w Katowicach, Katowice.

Bisaga A., 2013, Modernizacja sieciowa rolnictwa województwa opolskiego. Znaczenie aglomeracji opolskiej, [w:] A. Zagórowska (red.), Problemy Ślq̨ska ze szczególnym uwzględnieniem województwa opolskiego wyzwaniem dla ekonomii społecznej, Regionalny Ośrodek Polityki Społecznej w Opolu, Opole, s. 225-231.

Bisaga A., Sokołowska S., Szwiec P., 2010, Endogenne i egzogenne warunki trwałego rozwoju towarowych gospodarstw rolnych regionu opolskiego, Wydawnictwo Uniwersytetu Opolskiego, Opole.

Bruska A., 2014, Marnotrawstwo zasobów lokalnych na obszarach wiejskich w kontekście zrównoważonego rozwoju - próba identyfikacji problemu, Journal of Agribusiness and Rural Development, 2, s. 27-33.

Castells M., 2011, Społeczeństwo sieci, Wydawnictwo Naukowe PWN, Warszawa.

Czaja S., 2013, Wybrane problemy metodyczno-metodologiczne wyceny elementów kapitału naturalnego, Prace Naukowe UE we Wrocławiu, 317, Wrocław, s. 272-290.

Czudec A., Kata R., 2013, Miejsce rolnictwa w gospodarce regionów - wzajemne relacje i ich znaczenie ekonomiczne, Roczniki Naukowe SERiA, XV, 2, s. 58-63.

Czyżewski A., Smędzik-Ambroży K., 2013, Intensywne rolnictwo w procesach specjalizacji i dywersyfikacji produkcji rolnej. Ujęcie regionalne i lokalne, Wydawnictwo Naukowe PWN, Warszawa.

Hardt t., 2008, Wspólna polityka rolna a polityka spójności w kontekście przeglaqdu budżetu UE, Wieś i Rolnictwo, 4 (141), s. 47-65.

Koncepcja Przestrzennego Zagospodarowania Kraju 2030, Monitor Polski z dn. 27 kwietnia 2012, Poz. 252

Kulawik J., 2008, Efektywność finansowa rolnictwa. Istota, pomiar i perspektywy, Zagadnienia Ekonomiki Rolnej, 2, s. 33-53.

Niemczyk J., 2013, Strategia. Od planu do sieci, Wydawnictwo UE we Wrocławiu, Wrocław.

North D.C., 1997, Understanding Economic Change, [w:] J.M. Nelson, Ch. Tilly, L. Walker (red.), Transforming Post-Communist Political Economies, National Academy Press, Washington D.C, s. $13-18$.

Pietrzyk I., 2001, Polityka regionalna Unii Europejskiej i regiony w państwach członkowskich, PWN Warszawa.

Rozporzqdzenie Parlamentu Europejskiego i Rady (UE) Nr 1308/2013 ustanawiajqce wspólnq organizację rynków produktów rolnych, COM (2013) 1308.

Sokołowska S., Bisaga A., Szwiec P., 2006, Zmiany w organizacji i produktywności rolnictwa indywidualnego w procesie integracji z Uniq Europejska, Wydawnictwo Uniwersytetu Opolskiego, Opole.

Tomczak F., 2009, Wyzwania i sity rozwojowe wsi i rolnictwa w warunkach globalizacji gospodarki światowej, [w:] K. Duczkowska-Małysz, A. Szymecka (red.), Wokół trudnych problemów globalnego rozwoju obszarów wiejskich, gospodarki żywnościowej i rolnictwa, Oficyna Wydawnicza SGH, Warszawa, s. 171-193.

Zegar J. St., 2012, Współczesne wyzwania rolnictwa, Wydawnictwo Naukowe PWN, Warszawa.

Zegar J. St., 2014, Zrównoważenie rolnictwa woj. opolskiego na tle kraju, Studia KPZK PAN, 154, s. 83-100. 


\section{Summary}

After 10 years of Poland's accession to the EU, the CAP instruments have strengthen the development of merchandise agricultural households, adjusted them for managing environmental functions and have initiated the process of adapting to the knowledge based economy. The paper attempts to determine the impact of CAP and its institutional environment on the development of merchandise agricultural households in Opole region. The study was conducted with the method of questionnaire interview addressed to supervisors of the above mentioned households located in the representative agricultural areas of Opole region. Based on the research conducted in 2008 and 2014 it has been stated that further transformation processes concerning rural areas will depend on the "implantation" in the social networks of farmers in the existing, implemented institutional environment and on the estimation of impact they exert on changes in agricultural households on different levels of their functioning. 